\title{
INNOWACYJNOŚĆ JAKO PRZEJAW PRZEDSIĘBIORCZOŚCI POLSKICH PODMIOTÓW GOSPODARCZYCH
}

\author{
Ewa Kempa \\ Politechnika Częstochowska \\ Wydział Zarządzania
}

\begin{abstract}
Streszczenie: W opracowaniu przedstawiono problematykę związaną z rozwojem przedsiębiorczości oraz sposobami działania przedsiębiorcy w zmieniających się warunkach rynkowych. Zwrócono również uwagę na poziom przedsiębiorczości w Polsce, szczególnie w sektorze MŚP, oraz na przykładowe formy pomocy rządowej dla podmiotów chcących wdrażać innowacyjne rozwiązania. W artykule dokonano również próby oceny znaczenia innowacyjności dla rozwoju przedsiębiorczości w polskich podmiotach gospodarczych.
\end{abstract}

Słowa kluczowe: innowacyjność, działalność gospodarcza, przedsiębiorczość

DOI: $10.17512 /$ znpcz.2017.4.2.03

\section{Wprowadzenie}

Innowacyjność w połączeniu z przedsiębiorczością ma szansę stać się kluczowym czynnikiem wpływającym na sukces gospodarczy. Można próbować go osiągnąc poprzez podejmowanie mądrych i dojrzałych decyzji, inspirowanych poszukiwaniem zastosowania dla istniejących już rozwiązań w nowych dziedzinach. Aby przetrwać w nowej rzeczywistości gospodarczej, organizacje powinny umieć przewidywać i oceniać zdolności efektywnego działania oraz podejmować decyzje wpływające na tempo i możliwości własnego rozwoju (Rybak 2013, s. 17). Kluczem do sukcesu może okazać się właśnie przedsiębiorczość, która w połączeniu z postawami i działaniami innowacyjnymi wpływa na wzrost konkurencyjności na rynku. Celem opracowania jest zwrócenie uwagi na poziom innowacyjności polskich przedsiębiorstw oraz jej znaczenie dla potrzeb rozwoju przedsiębiorczości.

\section{Definicja i istota przedsiębiorczości}

Zmieniające się otoczenie zewnętrzne powoduje duże zapotrzebowanie na działania pozwalające złagodzić skutki kryzysu gospodarczego, kryzysu emigracyjnego czy dostosowanie się do globalnych potrzeb rynkowych. Taka sytuacja zwiększa popyt na kreatywność i działania przedsiębiorcze, które pozwalają i ułatwiają prowadzić biznes.

Davidsson wyróżnił trzy rodzaje definicji przedsiębiorczości (por.: Kurczewska 2013, s. 31-32): 
„Poprzez określenie rezultatów przedsiębiorczości. Zdaniem Schumpetera: »Przedsiębiorczość to działalność, która polega na wprowadzaniu nowych kombinacji czynników produkcji, nowych wyrobów i metod, na zdobywaniu nowych rynków zbytu i nowych źródeł zaopatrzenia oraz na tworzeniu nowych, bardziej efektywnych form działalności gospodarczej. Przedsiębiorczość prowadzi do innowacji i zmian technologicznych, tym samym przyczyniając się do wzrostu gospodarczego«.

Poprzez określenie procesów $i$ zdarzeń będacych sktadowymi elementami przedsiębiorczości. Shane i Vankataraman uważają, że: »Przedsiębiorczość jest procesem, dzięki któremu nowa wiedza przekształcana jest w produkty i usługi«. Poprzez określenie umiejętności charakteryzujacych przedsiębiorcę. Cooper uważa, że »Przedsiębiorczość to przede wszystkim zachowanie przedsiębiorcze oznaczające umiejętność korzystania z pojawiających się sposobności w otoczeniu społeczno-ekonomicznym«".

Okres gospodarki rynkowej spowodował wzrost przedsiębiorczości w wielu obszarach gospodarczych, czego efektem jest powstawanie nowych przedsiębiorstw szczególnie z obszaru MŚP. Po okresie transformacji w Polsce działa 1,84 mln przedsiębiorstw, wśród których dominują mikroprzedsiębiorstwa w liczbie 1,76 mln, co stanowi 95,7\% ogółu. W całej Unii Europejskiej zdecydowanie dominuje sektor MŚP. W Polsce również stanowi on $99,8 \%$ wszystkich działających podmiotów. Przy tym w przeciwieństwie do Polski w strukturze przedsiębiorstw unijnych więcej jest małych firm, a mniej mikroprzedsiębiorstw. W ciągu ostatnich 15 lat liczba przedsiębiorstw w naszym kraju wzrosła o ponad 230 tys. (PARP 2016b, s. 7), co świadczy o rozwoju przedsiębiorczości wśród Polaków.

\section{Przedsiębiorca na rynku pracy}

Rynek pracy w Polsce jest oceniany jako stosunkowo elastyczny, przedsiębiorcy mają możliwość dostosowywania wysokości płac do swoich wymagań, a koszty zwolnień pracowników są niskie. Problemem jest efektywne wykorzystanie zasobów na rynku pracy. W 2014 roku udział osób aktywnych zawodowo w wieku od 20 do 64 lat stanowił zaledwie 66,5\% (PARP 2017, s. 40). To właśnie wysokie bezrobocie wśród ludzi młodych było jedną z przyczyn wyjazdów zarobkowych Polaków, którzy często nie mogli odnaleźć się w polskiej rzeczywistości rynkowej.

$\mathrm{W}$ ostatnim czasie zdecydowanie zmienił się rynek pracy w Polsce, co spowodowane było zwiększonym popytem na pracowników (nie oznacza to, że nie muszą oni dostosować swoich kwalifikacji do potrzeb pracodawcy). Wielu potencjalnych pracowników, szczególnie młodych, podnosząc kwalifikacje zawodowe, decyduje się jednak na założenie własnego biznesu i bycie przedsiębiorcą. Często wymaga to nie tylko stałego dostosowania wykształcenia do potrzeb rynkowych, ale także zwiększenia własnej mobilności i odporności na stres, który jest nieodzowną częścią prowadzenia działalności gospodarczej.

Zgodnie z badaniami PARP przeciętny przedsiębiorca w Polsce - bez względu na to, czy jest pracodawcą, czy prowadzi firmę jednoosobową - ma 44 lata. Spośród wszystkich grup pracujących w Polsce przedsiębiorcy są najstarsi. Europejscy 
samozatrudnieni są średnio o rok starsi, a pracodawcy o 3 lata. W Polsce wśród samozatrudnionych mamy 66\% mężczyzn i 34\% kobiet, a wśród pracodawców 69\% mężczyzn i 31\% kobiet. W porównaniu z UE wśród pracodawców w Polsce można zaobserwować większy odsetek kobiet (PARP 2016b, s. 40), które z powodzeniem prowadzą własne biznesy.

Zarządzający powinien rozumieć otoczenie, w którym funkcjonuje jego organizacja, ale także wiedzieć, jak postrzegana jest przedsiębiorczość, co może pomóc w kierowaniu biznesem. Dotyczy to zarówno motywów podjęcia działań przedsiębiorczych, zachowań społecznych, ale także ich postrzegania w środkach masowego przekazu. Posiadane przez menedżerów kompetencje mogą mieć także kluczowe znaczenie dla formułowania i wdrażania nowych strategii rozwojowych organizacji (Gostkowska-Dźwig, Mrozik 2013, s. 105). Okres gospodarki rynkowej w Polsce jest stosunkowo krótki, dlatego warto zestawić jego efekty z innymi krajami działającymi w porównywalnych warunkach rynkowych.

Przedsiębiorca, podejmując decyzje strategiczne, kieruje się przede wszystkim rozsąadkiem, ale czasami również towarzyszącymi mu odczuciami i emocjami, a należą do nich najczęściej (por.: Kurczewska 2013, s. 13-125):

Obecność osób trzecich. Najczęściej są nimi osoby najbliższe przedsiębiorcy, tj. rodzina, partnerzy i przyjaciele, których współudział w procesie zmniejsza ryzyko popełnienia ewentualnych błędów i daje satysfakcję z dzielenia się sukcesem.

Wsparcie psychiczne i emocjonalne. Przedsiębiorcy często wykazują niepewność w podejmowaniu decyzji, dlatego oczekują wsparcia psychicznego, które utwierdziłoby ich w słuszności podjętej przez siebie decyzji. Wsparcie psychiczne i emocjonalne osób „patrzących z boku” na przedsięwzięcie może być cenniejsze niż pomoc kogoś zaangażowanego merytorycznie.

- $\quad$ Potwierdzenie słuszności realizowania pomysłów. Niepewność w podjęciu decyzji powoduje chęć poszukiwania osób, które realizowały podobny projekt i odniosły sukces. Takie działania spowodowane są niepewnością i niewiarą we własne możliwości oraz chęcią uniknięcia jak największej liczby błędów.

Emocje. Podejmowaniu strategicznych decyzji zwykle towarzyszą emocje. Te pozytywne związane są z entuzjazmem, ekscytacją i radością, natomiast negatywne to strach przed brakiem sukcesu oraz obawa przed nieznanym.

Kontrola nad procesem. Wielu przedsiębiorców czuje się pewniej, mając wpływ na wszystkie działania podejmowane w procesie wdrażania pomysłów.

Informacje. Są istotnym elementem podejmowania decyzji strategicznych, gdyż dają pewność ich słuszności. Źródłem informacji może być zarówno Internet, jak i literatura, ale także wywiad środowiskowy przeprowadzany wśród zainteresowanych daną branżą.

Inspiracja. Często jest potrzebna do podjęcia decyzji, a jej źródłem mogą być zarówno bliskie osoby, jak i idole, którzy osiągnęli sukces, a znani są tylko z Internetu lub telewizji.

Polscy przedsiębiorcy są zazwyczaj wyjątkowo ostrożni w pozytywnej ocenie sytuacji rynkowej, często towarzyszy im strach przed porażką. Dlatego osób po- 
dejmujących wyzwania przedsiębiorcze jest znacznie mniej niż tych, które co prawda deklarują taką gotowość, ale nie podejmują tego ryzyka.

\section{Przedsiębiorczość w Polsce}

Istotą przedsiębiorczości jest podejmowanie działań ułatwiających rozwiązywanie problemów oraz przynoszących korzyści danej organizacji, poprzez wyszukiwanie i wykorzystywanie szans pojawiających się w otoczeniu. Mogą być one związane z wyprowadzeniem na rynek nowych produktów, zawarciem ciekawych kontaktów biznesowych czy utworzeniem nowego przedsięwzięcia. Skala przedsiębiorczości w Polsce stale rośnie, o czym może świadczyć ilość powstających podmiotów, szczególnie z sektora MŚP. Jaka jest liczba i struktura aktywnych przedsiębiorstw w Polsce w latach 2010-2014, przedstawiono w Tabeli 1.

Tabela 1. Ogólna liczba aktywnych przedsiębiorstw w Polsce w poszczególnych grupach według wielkości w latach 2010-2014 [tys.]

\begin{tabular}{|c|c|c|c|c|c|c|c|c|c|c|}
\hline \multirow{2}{*}{$\begin{array}{l}\text { Podzial wg } \\
\text { wielkości } \\
\text { zatrudnienia }\end{array}$} & \multicolumn{10}{|c|}{ Lata } \\
\hline & 2010 & $\%$ & 2011 & $\%$ & 2012 & $\%$ & 2013 & $\%$ & 2014 & $\%$ \\
\hline $1-9$ & 1655,1 & 95,85 & 1710,6 & 95,85 & 1719,2 & 95,78 & 1693,8 & 95,61 & 1764,6 & 95,77 \\
\hline $10-49$ & 52,6 & 3,05 & 55,0 & 3,09 & 57,1 & 3,18 & 59,1 & 3,35 & 59,2 & 3,21 \\
\hline $50-249$ & 15,8 & 0,92 & 15,8 & 0,88 & 15,5 & 0,86 & 15,3 & 0,86 & 15,5 & 0,84 \\
\hline Pow. 249 & 3,2 & 0,18 & 3,2 & 0,18 & 3,2 & 0,18 & 3,2 & 0,18 & 3,4 & 0,18 \\
\hline Ogółem & 1726,7 & 100,00 & 1784,6 & 100,00 & 1794,9 & 100,00 & 1771,5 & 100,00 & 1842,6 & 100,00 \\
\hline
\end{tabular}

Źródło: Opracowanie własne na podstawie (PARP 2016a, s. 4)

Dane zawarte w Tabeli 1 pokazują, że struktura podmiotów gospodarczych w Polsce jest zdominowana przez sektor MŚP. W badanych latach zdecydowanie najwięcej było mikroprzedsiębiorstw, których liczba stale rosła. Wyjątkiem był rok 2013, w którym ilość aktywnych przedsiębiorstw zatrudniających do 9 osób była minimalnie mniejsza. Warto też zaobserwować wzrost liczby podmiotów o zatrudnieniu 10-49 osób, co może świadczyć o rozwoju mikroprzedsiębiorstw, które zatrudniają więcej pracowników. W badanym okresie ilość dużych przedsiębiorstw jest mniej więcej na stałym poziomie, ale stanowi jedynie $0,18 \%$ ogólnej liczby aktywnych przedsiębiorstw w Polsce.

Każdego roku w naszym kraju zakładanych jest wiele nowych podmiotów, niestety odnotowuje się również dużo bankructw i przypadków zakończenia działalności. Duża konkurencja na rynku, złe przygotowanie do prowadzenia biznesu oraz kłopoty na rynku wewnętrznym mogą stanowić powód likwidacji podmiotów. $\mathrm{W}$ takiej sytuacji stają nie tylko przedsiębiorcy nowi na rynku, ale zdarza się to także tym, którzy działali na nim dłużej. Jaka ilość podmiotów powstała oraz jaka upadła w badanym okresie, pokazano w Tabeli 2. 
Tabela 2. Liczba przedsiębiorstw nowo powstałych i zlikwidowanych w latach 2010-2014

\begin{tabular}{|l|c|c|c|c|c|}
\hline \multicolumn{1}{|c|}{ Lata } & $\mathbf{2 0 1 0}$ & $\mathbf{2 0 1 1}$ & $\mathbf{2 0 1 2}$ & $\mathbf{2 0 1 3}$ & $\mathbf{2 0 1 4}$ \\
\hline $\begin{array}{l}\text { Liczba przedsiębiorstw } \\
\text { nowo powstałych [tys.] }\end{array}$ & 270 & 247 & 229 & 250 & 253 \\
\hline $\begin{array}{l}\text { Liczba przedsiębiorstw } \\
\text { zlikwidowanych [tys.] }\end{array}$ & 207 & 225 & 223 & 258 & $\begin{array}{c}\text { brak } \\
\text { danych }\end{array}$ \\
\hline
\end{tabular}

Źródło: Opracowanie własne na podstawie (PARP 2016a, s. 4)

Dane zawarte w Tabeli 2 wyraźnie wskazują, że w badanych latach ilość nowo powstałych przedsiębiorstw jest mniej więcej na tym samym poziomie, tj. około 250 tys. (z wyjątkiem roku 2012, kiedy powstało 229 tys. przedsiębiorstw). Liczba zlikwidowanych firm w każdym roku wynosi ponad 200 tys. (rok 2014 - brak danych), najmniej (207 tys.) w 2010 r., a najwięcej (258 tys.) w 2013 r. Liczba zlikwidowanych przedsiębiorstw w każdym roku jest zbliżona do liczby nowo powstałych (w 2013 r. była większa). Nie oznacza to jednak, że likwidowane są podmioty powstałe w tym samym roku. Czasami kończy się działalność firmy, która istniała na rynku wiele lat, a teraz właściciele muszą (np. z powodu niewypłacalności) lub chcą ją zlikwidować (np. zmiana profilu działalności i wyjście z sektora).

Ilość likwidowanych przedsiębiorstw wyraźnie wskazuje, że wielu przedsiębiorców potrzebuje wsparcia zarówno merytorycznego, jak i finansowego. Naprzeciw oczekiwaniom wychodzi Ministerstwo Rozwoju, które proponuje wsparcie finansowe ze środków budżetowych, stwarzające dobre możliwości rozwoju firm. Wsparcie to pomoże przedsiębiorstwom m.in. (https://www.mr.gov.pl/...):

poprawić konkurencyjność na rynku krajowym, unijnym i międzynarodowym; poprawić sytuację ekonomiczną; otrzymać analizy konkurencyjności w różnych sektorach;

zwiększyć własne inwestycje w uzyskanie dostępu do profesjonalnego wsparcia biznesu - instytucjonalnego, organizacyjnego i finansowego;

zwiększyć dostępność kapitału.

Podmiotom będącym eksporterami możliwe jest udzielenie dotacji - refundacji za poniesione wydatki kwalifikowane, którymi są (https://www.mr.gov.pl/...):

Dofinansowanie branżowych projektów promocyjnych. Kierowane do grup co najmniej czterech przedsiębiorców w ramach tej samej lub kilku pokrewnych branż lub grup towarowych, wykonujących działalność gospodarczą w Polsce. Ma na celu promowanie określonych produktów i grup towarowych o wysokim potencjale eksportowym. Wysokość wsparcia to max. 100 tys. zł i 50\% kosztów kwalifikowanych. Limit dofinansowania dla jednego przedsiębiorcy wynosi 8 tys. zł.

Dofinansowywanie kosztów organizacji przedsięwzięć promocyjnych. Ma na celu wspieranie organizacji przedsięwzięć promocyjnych o proeksportowym charakterze, jak np. konferencje, seminaria itp. Dofinansowanie obejmuje max. 
$50 \%$ kosztów kwalifikowanych związanych np. z obsługą techniczną, wynajęciem sali itp.

Dofinansowanie publikacji wydawnictw i materiałów promocyjnych. Kierowany do wydawnictw promujących eksport lub sprzedaż na rynku wewnętrznym UE więcej niż jednego przedsiębiorcy. Dofinansowanie obejmuje max. 50\% kosztów kwalifikowanych.

Dofinansowanie kosztów uzyskania certyfikatów wyrobów eksportowych. Wsparcie mikro, małych i średnich firm w uzyskaniu certyfikatów wyrobów eksportowych, wymaganych na rynkach zagranicznych, z wyjątkiem certyfikatów wymaganych na rynku wewnętrznym Unii Europejskiej. Dofinansowanie wynosi max. 50 tys. zł i obejmuje 50\% kosztów kwalifikowanych.

Każda z powyższych form pomocy jest szczególnie cenna dla innowacyjnych przedsiębiorców, gdyż pozwala im na rozwój i możliwość zaistnienia na rynkach międzynarodowych.

\section{Znaczenie innowacyjności dla rozwoju przedsiębiorstw}

Duża konkurencja w gospodarce wymusza na przedsiębiorcach poszukiwanie innowacyjnych rozwiązań pozwalających na wprowadzane nowych produktów, lepiej zaspokajających potrzeby rynku, konsumentów oraz środowiska. Rozwiązania te wymagają jednak wyższego poziomu edukacji innowacyjnej, pociągając za sobą duże nakłady finansowe, które często gotowe są ponieść jedynie organizacje lepiej rozwijające się i świadome znaczenia rozwoju nowych technologii na rynku globalnym.

Stale zmieniające się otoczenie powoduje nieustanną potrzebę przyswajania nowych myśli technologicznych, a ich poziom jest zwykle zdeterminowany sytuacją wewnętrzną $\mathrm{w}$ firmie oraz zewnętrznymi warunkami prowadzenia działalności. Tylko przedsiębiorstwa innowacyjne mają możliwość zaspokoić wymagania odbiorców, a warunki globalnego otoczenia wykorzystać do własnego rozwoju (Decyk, Juchniewicz 2014, s. 379).

Innowacyjność w przedsiębiorstwie może obejmować nie tylko technologię, ale także marketing i organizację. W młodych sektorach konkurencja koncentruje się na pozyskaniu nowej technologii wyrobu, która pozwala na przyciągniecie klientów poszukujących nowatorskich produktów i usług. Faza powstawania nowego sektora rozpoczętego nieznaną dotąd technologią trwa krótko. Jednak cykle jego życia można wydłużyć poprzez inwestycje nie w nowe generacje technologii, ale w innowacje zwiększające funkcjonalność i trwałość produktu, a także w innowacje zmniejszające koszty wytworzenia danego wyrobu (Romanowska 2009, s. 213).

Wzrastająca konkurencja na rynku wewnętrznym i zewnętrznym powoduje, że coraz więcej małych i średnich przedsiębiorstw w Polsce stawia na innowacyjność, co zazwyczaj wymaga jednak zwiększonych nakładów finansowych. Większość podmiotów nie ma możliwości sfinansowania inwestycji ze środków własnych, dlatego stara się korzystać z innych form wsparcia, np. dotacji budżetowych czy unijnych. 
Innowacyjność przedsiębiorstw w Polsce nadal odbiega od średniej unijnej, pomimo znacznego wzrostu w ostatnich latach nominalnej wartości nakładów na badania i rozwój. Niski poziom współpracy biznesu z naukowcami, wysokie ryzyko wdrożeń oraz brak zachęt po stronie rynku (duży rynek wewnętrzny zapewnia zadowalający poziom popytu) to jedne z podstawowych przyczyn niskiego poziomu innowacyjności przedsiębiorstw w Polsce (Przedsiębiorczość w Polsce 2016, s. 40).

Zgodnie z publikowanym przez Komisję Europejską rankingiem European Innovation Scoreboard 2016 - Polska zajmuje 23. pozycję wśród 28 klasyfikowanych państw. Pomimo niskiego poziomu wydatków na badania i rozwój pozycję Polski poprawia stosunkowo wysoka skłonność polskich spółek do inwestycji (14. miejsce $\mathrm{w}$ rankingu). Ponadto innowacyjność jest doceniana za (por.: Białek-Jaworska, Ziembiński, Zięba 2016, s. 12):

aktywa oparte na wiedzy, czyli posiadanie dużej liczby znaków towarowych i wzorów przemysłowych;

zasoby ludzkie, czyli dużą liczbę osób z wykształceniem powyżej średniego i nadanych stopni doktora;

finansowanie, czyli wydatki sektora publicznego na B+R.

Badania przeprowadzone przez Ministerstwo Rozwoju wykazały, że najczęściej innowacyjnymi działami przemysłu są: produkcja wyrobów farmaceutycznych, wyrobów chemicznych oraz produkcja koksu i produktów rafinacji ropy naftowej (w latach 2012-2014 odpowiednio 45,6\%, 38,9\% i 38,6\% przedsiębiorstw z tych działów wprowadzało innowacje). W tym samym okresie najmniej innowacyjne okazały się podmioty działające w produkcji odzieży $(6,2 \%)$ oraz skór $(9,6 \%)$. $\mathrm{W}$ usługach najbardziej innowacyjny był dział ubezpieczeń, reasekuracji i funduszy emerytalnych oraz dział badań naukowych i prac rozwojowych (w latach 2012-2014 odpowiednio 64,8\% i 33,6\% przedsiębiorstw w tych działach można było uznać za innowacyjne). W tym samym okresie najmniej innowacyjnych podmiotów było $\mathrm{w}$ transporcie lądowym rurociągowym $(6 \%)$ oraz $\mathrm{w}$ architekturze i analizach technicznych (7,8\%) (Przedsiębiorczość w Polsce 2016, s. 41).

Jaka część pomiotów (z pominięciem mikroprzedsiębiorstw) $\mathrm{z}$ branży przemysłowej i usługowej zdecydowała się na innowacyjność w latach 2012-2015, pokazuje Rysunek 1. Badaniu zostały poddane przedsiębiorstwa z bazy STRATEG (system stworzony przez GUS na potrzeby programowania i monitorowania polityki rozwoju). 


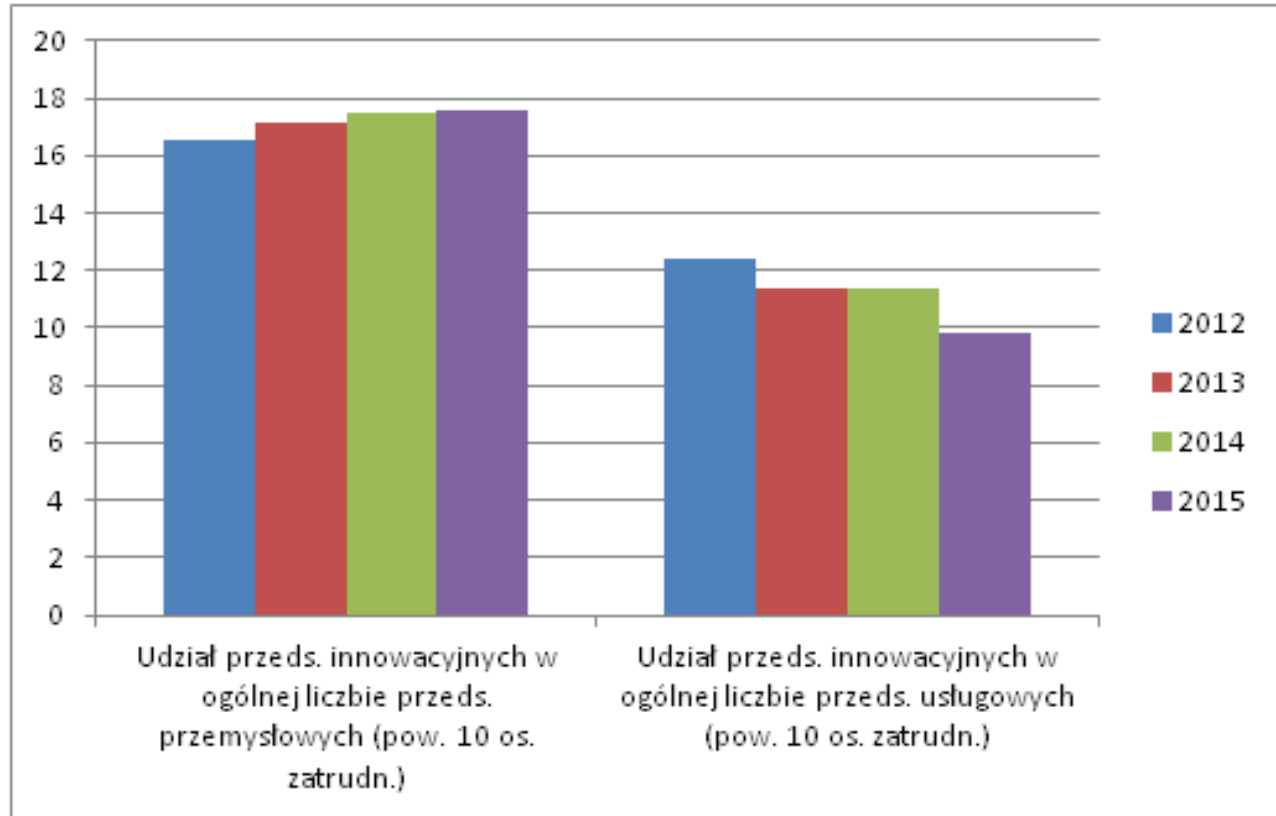

Rysunek 1. Udział przedsiębiorstw innowacyjnych (przemyslowych i usługowych) w bazie STRATEG

Źródło: Opracowanie własne na podstawie (GUS 2016)

Na Rysunku 1 wyraźnie widać, że w badanych latach bardziej innowacyjne były przedsiębiorstwa przemysłowe, chociaż ich ilość nie przekraczała $18 \%$. Zdecydowanie mniej na innowacje wydawały przedsiębiorstwa usługowe, najwięcej w roku 2012, a najmniej w 2015, co wskazuje na dość niepokojącą tendencję spadkową.

Mała innowacyjność Polski wynika z niskich nakładów na badania i rozwój krajowych przedsiębiorstw oraz gorszych od średnich wyników polskich naukowców w porównaniu z innymi krajami. Na tle Unii mamy jednak pięć przewag: odsetek populacji z wyższym wykształceniem, odsetek młodych osób, które skończyły przynajmniej liceum lub zawodówkę, wyższe od średniej wydatki przedsiębiorstw na innowacyjność (np. marketingową, ale nie na badania i rozwój), liczbę chronionych wzorów przemysłowych oraz rosnące zatrudnienie w rozwijających się sektorach gospodarki. Mamy więc w Polsce bazę do tego, by zwiększyć w przyszłości zaawansowanie technologiczne naszej gospodarki (Arak (red.) 2016, s. 41).

Ważne jest jednak wsparcie polskich przedsiębiorców w zakresie prawodawstwa ułatwiającego wdrażanie innowacyjności, tworzenie programów rządowych wspierających polską myśl intelektualną oraz badania i rozwój.

\section{Podsumowanie}

Przedsiębiorczość w Polsce rozwija się w szybkim tempie, a Polacy stale pokazują, że mogą swobodnie konkurować z Europejczykami w wielu dziedzinach związanych z zarządzaniem i prowadzeniem działalności gospodarczej. Jest wiele 
czynników motywujących do podejmowania działań przedsiębiorczych, ale również wiele barier utrudniających ich wprowadzenie (Kościelniak 2015, s. 196). Jedną $\mathrm{z}$ nich może być niski poziom innowacyjności $\mathrm{w}$ polskich przedsiębiorstwach (co potwierdziły przeprowadzone badania - Rysunek 1), pomimo stałego podwyższania kwalifikacji pracowników i lepszego rozeznania na rynkach zagranicznych. Dlatego szansą dla podmiotów jest korzystanie z programów ministerialnych i unijnych, dzięki którym mogą one zgromadzić środki na bieżącą działalność i rozwój bądź pozyskanie nowych technologii.

Przedsiębiorcy powinni również zachęcać pracowników do większego zainteresowania działaniami innowacyjnymi, które mają prowadzić do zwiększenia wydajności i osiągnięcia przewagi konkurencyjnej podmiotu. Dlatego warto inwestować w bieżące szkolenia z zakresu m.in. zarządzania i marketingu, które mają na celu rozwijanie przejawów przedsiębiorczości (Sulistyo, Siyamtinah 2016, s. 196-203).

Przeprowadzone badania pokazały, że w Polsce powstaje coraz więcej podmiotów, szczególnie z sektora MŚP, ale jednocześnie każdego roku likwidowanych jest wiele firm, które nie wytrzymują konkurencji. Jednym z powodów takiego stanu rzeczy może być niski poziom albo brak innowacyjności, co ogranicza potencjał przedsiębiorczy na rynku.

\section{Literatura}

Arak P. (red.) (2016), Ukryta innowacyjność polskich biznesów, DELab UW, Polska Rada Biznesu, http://www.delab.uw.edu.pl/raport/1/index.html (dostęp: 01.04.2017).

Białek-Jaworska A., Ziembiński M., Zięba D. (2016), Innowacyjność polskich przedsię-

2. biorstw. Działalność badawczo-rozwojowa $i$ wspótpraca nauki z biznesem, Polska Rada Biznesu, http://www.delab.uw.edu.pl/ (dostęp: 01.04.2017).

3. Decyk K., Juchniewicz M. (2014), Poziom i cele działalności innowacyjnej mikroprzedsiębiorstw, „Przedsiębiorczość i Zarządzanie”, t. 15, z. 7, s. 379-391.

4. GUS (2016), Działalność innowacyjna przedsiębiorstw w latach 2013-2015, Główny Urząd Statystyczny, Warszawa, https://stat.gov.pl/obszary-tematyczne/nauka-i-technika-spoleczenstwo-informacyjne/nauka-i-technika/dzialalnosc-innowacyjna-przedsiebiorstw-w-latach-

5. 2013-2015,2,14.html (dostęp: 30.03.2017).

Gostkowska-Dźwig S., Mrozik M. (2013), Przedsiębiorcze działania w aspekcie integracji procesów zarządzania, [w:] Mrozik M., Gostkowska-Dźwig S. (red.), Przedsiębiorczość a rozwój przedsiębiorstw, Sekcja Wydawnictw Wydziału Zarządzania Politechniki Częstochowskiej, Częstochowa, s. 105-112.

7. https://www.mr.gov.pl/strony/zadania/wsparcie-przedsiebiorczosci/o-wsparciu-przedsiebiorczosci (dostęp: 01.04.2017).

Kościelniak H. (2015), Controlling działań przedsiębiorczych przedsiębiorstw, [w:] Gostkowska-Dźwig S., Mrozik M. (red.), Wyzwania i perspektywy przedsiębiorczej organizacji. Tom IV: Konkurencja, innowacja, koncepcje zarządzania, Sekcja Wydawnictw Wydziału Zarządzania Politechniki Częstochowskiej, Częstochowa, s. 190-197.

Kurczewska A. (2013), Przedsiębiorczość, PWE, Warszawa.

PARP (2016a), Przedsiębiorczość w Polsce 2016 - wybrane dane z Raportu o stanie sektora MSP, Polska Agencja Rozwoju Przedsiębiorczości, Warszawa, https://badania.parp.gov.pl/ attachments/article/47875/Przedsi\%C4\%99biorczo\%C5\%9B\%C4\%87\%20w\%20Polsce\% 202016\%20-\%20wybrane\%20dane.pdf (dostęp: 01.04.2017). 
PARP (2016b), Raport o stanie sektora MSP w Polsce, Polska Agencja Rozwoju Przedsiębiorczości, Warszawa, https://www.parp.gov.pl/images/PARP_publications/pdf/2016_raport msp_pl_clik.pdf (dostęp: 01.04.2017).

PARP (2017), Perspektywy rozwoju polskiej branży ICT do roku 2025, raport przygotowany przez INVESTIN na zlecenie Ministerstwa Rozwoju, Polska Agencja Rozwoju Przedsiębiorczości, Warszawa, https://www.parp.gov.pl/images/PARP_publications/pdf/2017 _ict_sector_by_2025_pl.pdf(dostęp: 01.04.2017).

Przedsiębiorczość w Polsce 2016, www.mr.gov.pl (dostęp: 30.03.2017).

Romanowska M. (2009), Planowanie strategiczne w przedsiębiorstwie, PWE, Warszawa. Rybak A. (2013), Restrukturyzacja portfela ustug w branży IT - studium przypadku, [w:] Mrozik M., Gostkowska-Dźwig S. (red.), Przedsiębiorczość a rozwój przedsiębiorstw, Sekcja Wydawnictw Wydziału Zarządzania Politechniki Częstochowskiej, Częstochowa, 12. s. 11-37.

13. Sulistyo H., Siyamtinah (2016), Innovation Capability of SMEs Through Entrepreneurship, 14. Marketing Capability, Relational Capital and Empowerment, „Asia Pacific Management Review”, Vol. 21, Issue 4, s. 196-203. DOI: 10.1016/j.apmrv.2016.02.002

15.

\title{
INNOVATIVENESS AS A CHANCE OF THE ENTREPRENEURS OF POLISH ECONOMIC ENTITIES
}

\begin{abstract}
The study presents the issues related to the development of entrepreneurship and the ways the entrepreneur operates in changing market conditions. Attention was also paid to the level of entrepreneurship in Poland, especially in the SME sector, as well as examples of government assistance for enterprises wishing to implement innovative solutions. The article also attempts to assess the level of innovativeness of entities in Poland.
\end{abstract}

Keywords: innovation, business activity, entrepreneurship 